\title{
GROWTH AND PRODUCTIVITY OF SOYBEAN (GLYCINE MAX (L.) MERR.) GENOTYPES UNDER SHADING
}

\author{
WAHYUNINGSIH, S. - SUNDARI, T. - SUTRISNO - HARNOWO, D. - HARSONO, A. - SOEHENDI, R. \\ - MEJAYA, M. J. \\ Indonesian Legumes and Tuber Crops Research Institute (ILETRI), Jl. Raya Kendalpayak km. \\ 8., PO Box 66, Malang 65101, East Java, Indonesia \\ (phone: +62-341-801-468; fax: +62-341-801-496) \\ *Corresponding author \\ e-mail:mmejaya@yahoo.com; phone: +62-341-806-074
}

(Received 17th Mar 2021; accepted $19^{\text {th }}$ Jul 2021)

\begin{abstract}
The research was aimed to determine the growth of soybean genotypes under shading. This Research was conducted in Malang, East Java, Indonesia. Treatments entailed of two factors, namely level of shading and soybean genotypes, arranged in factorial randomized complete block design with three replications. Level shading entailed of without shading and 50\% shading, while soybean genotypes included of Argopuro, Dena 1, Dena 2, Dena 3, Grobogan, Panderman, and Karat 13. The results indicated that the soybean genotype responses to shading were different. Shading reduced leaf area index (LAI), net assimilation rate (NAR), and plant growth rate (PGR), however it increased the specific leaf area (SLA) and leaf area ratio (LAR Dena 1 genotype showed the lowest PGR stress intensity at 6\%, followed by Panderman $(16 \%)$ which are below the average of genotypes stress intensity at 56 DAP (24\%). The PGR had significantly positive correlation with seed yield. The average decrease in seed yields of 7 soybean genotypes were $32 \%$, and Dena 1 showed the most tolerant to shading. This proved wih the fact that of Dena 1 which is currently widely planted by the farmers in Indonesia on an intercropping pattern, or under shading of young plantation crops.
\end{abstract}

Keywords: intercropping, leaf area, net assimilation, stress intensity, tolerant

\section{Introduction}

In Indonesia, availability of land for soybean (Glycine max (L.) Merr.) monoculture cultivation is very limited because most of the land is used for estate plantations and other food crops, especially rice and maize. Therefore, expansion of the soybean planting area can be done by utilizing suboptimal land, especially dry land with intercrop system and among annual estate plant stands. Land available among other plant stands can be in the form of land under plantation stands, forest plants, and young estate plants (0-3 years), as well as land between rows of maize and cassava plants. Shaded lands which can be used for soybean development in Indonesia in the plantation, intercropping with maize, and intercropping with cassava were reaches to 1.7 million ha, 5.5 million ha, and 0.67 million ha, respectively (Mulyani et al., 2009; Statistics Indonesia, 2019).

Harsono et al. (2020) reported that the shade of maize crops above the canopy of soybean in the intercropping with maize (double row with spacing of $(40 \times 20) \mathrm{cm} \times$ $200 \mathrm{~cm}$ ) and soybean with pplants spacing of $30 \mathrm{~cm} \times 15 \mathrm{~cm}$ ) at the age of 40 and 60 days were $53-59 \%$ and $58-63 \%$, respectively. This condition causes a decrease in soybean yields of $40-44 \%$. In plantation lands, the levels of shade can reach $20-60 \%$, depending on type and age of plantation crops. Shade decreases the photosynthetic rate through reducing the production of ATPs in photosystem II (PSII) reaction center via blocking electron flow rate (Huang et al., 2018; Valladares and Niinemets, 2008). 
The morphological characteristics of soybean, biomass accumulation and distribution, and yield were significantly affected by shading stress Soybean is susceptible to shading effect of neighboring highstalked maize plants, hence reducing soybean yield (Liu et al., 2010). The characteristics that must be possessed by soybean genotypes in this condition are shading tolerance under shading conditions $<50 \%$. For this reason, soybean plants that are adaptive to shading are needed. Light is a source of energy for plant photosynthesis, and light intensity has an important influence on plant morphology, physiology, and reproduction (Li et al., 2010; Mauro et al., 2014; Wang et al., 2014). In each plant habitat, light intensity varies temporally (seasonally and daily) and spatially. Therefore, plants perform acclimatization and plasticity to overcome the light variation problem (Zhang et al., 2003). Soybean varieties which were exposed to shade stress showed an increased in plant heights and internode lengths, but reduced stem diameters and lignin accumulation in stems (Liu et al., 2018).

Leaf area is a basic component of leaf area index for crop production, which contributes to light interception of the entire plant canopy (Zhu, 2010; Evans, 2013). Hence, leaf area is important for plants to overcome shading. On the other hand, leaves are also involved in avoidance responses to shading. Leaf size is highly dependent on the number and size of cells. However, leaf area is not only determined by the number and size of cells, but also cell division, cell development and the overall tissue of the organ (Gonzalez et al., 2012). Besides being controlled by genetic factors, leaf area is also influenced by environmental factors including light. Shading promotes elongation of petioles and inhibits leaf development. Quantitative methods are used to describe and interpret the performance of all parts of the plant, namely plant growth analysis. Growth analysis is a method used to describe photosynthetic dynamics measured through dry matter production. Plant growth can be measured without damaging the plant, such as measuring plant height or leaf count, but this often lacks accuracy. Dry matter accumulation is more described as a measure of growth because it reflects the ability of plants to bind energy from sunlight through photosynthesis, as well as their interactions with other environmental factors (Sumarsono, 2008).

Shading reduced soybean seed yield $34-55 \%$ depending on population density and variety (Liu et al., 2010). The ability of genotypes to respond to shading stress (low light) is different, so that the selection of soybean genotypes that is suitable for the shading environment plays an important role (Polthanee et al., 2011). The objective of this study was to determine the plant growth of seven soybean genotypes under shading condition.

\section{Methodology}

\section{Place and time of study}

The research was conducted in Kendalpayak Research Station, Malang, East Java, Indonesia, in 2013.

\section{Research design}

The research consisted of two factors. The first factor was level of shading, namely without shading or non-shading and 50\% shading, while the second factor was seven soybean genotypes, consisted of Argopuro, Dena 1, Dena 2, Dena 3, Grobogan, Panderman, and Karat 13. Placement of treatment was based on a factorial complete randomized block design that was repeated three times. 
Each treatment unit was planted on a plot measuring $1.6 \mathrm{~m} \times 3.0 \mathrm{~m}$. Soybean seeds were planted at a spacing distance of $40 \mathrm{~cm} \times 15 \mathrm{~cm}$ and two seeds per hole. The $50 \%$ shading treatment came from two layers of black paranet mounted at a height of $1.8 \mathrm{~m}$. Shade treatment was applied from planting to harvesting.

Observations were made on the quantitative characters of plants, including total number of leaves per plant, leaf area calculated using a leaf area meter, and seed weight per plot. Observations were carried out destructively every two weeks, starting at the age of 28 days after planting (DAP) to 56 DAP. The method of sample selection was by removing three crops without affected the performance the remaining ones.

\section{Data analysis}

The growth analysis was calculated based on the model used by Gardner et al. (1985), namely:

1. Leaf area index (LAI) shows the ratio of the leaf surface to the land area occupied by the plant, calculated by the formula:

$$
L A I=\frac{[(L A i+(L A i-1)] / 2}{G a}
$$

where:

$\mathrm{LAi}$ and $\mathrm{LAi}-1=$ leaf area $\left(\mathrm{cm}^{2} /\right.$ plant $)$ at $\mathrm{Ti}$ and $\mathrm{Ti}-1$, respectively

$\mathrm{Ti}$ and Ti-1 $=$ plant age on day $\mathrm{i}$ and $\mathrm{i}-1$

$\mathrm{Ga}=$ Land area occupied by plants $\left(\mathrm{cm}^{2}\right)$

2. Specific leaf area (SLA) shows the thickness of the leaves based on leaf dry weight, calculated by the formula:

$$
S L A=\frac{[(L A i / L D W i)]+[(L A i-1) /(L D W i-1)]}{2}
$$

where:

LAi and LAi-1 = leaf area (cm2/plant) at plant age Ti and Ti-1, respectively

LDWi and LDWi-1 = leaf dry weight (g/plant) at Ti and Ti-1, respectively

3. Leaf area ratio (LAR) is the ratio between the tissue carrying out photosynthesis to the total plant tissue, calculated by the formula:

$$
L A R=\frac{[(L A i / T D W i)]+[(L A i-1) /(T D W i-1)]}{2}
$$

where:

LAi and LAi-1 = leaf area (cm2/plant) at plant age Ti and Ti-1, respectively TDWi and TDWi-1 = total dry weight (g/plant) of Ti and Ti-1, respectively.

4. Net assimilation rate (NAR) shows the net assimilation results, calculated by the formula:

$$
N A R=\frac{(T D W i-T D W i-1)}{(T-T i-1)}+\frac{(\ln L A i-\ln L A i-1)}{(L A i-L A i-1)}\left(\mathrm{g} / \mathrm{cm}^{2} / \text { week }\right)
$$


5. Plant growth rate (PGR) shows an increase in plant dry weight per unit land area in certain time intervals, calculated by the formula:

$$
P G R=\frac{[(T D W i-T D W i-1)] /[(T-T i-1)]}{G a}\left(\mathrm{~g} / \mathrm{cm}^{2} / \mathrm{day}\right)
$$

where:

TDWi and TDWi-1 = total dry weight $=$ leaf dry weight + root dry weight $(\mathrm{g} / \mathrm{plant})$ at plant age of Ti and Ti-1, respectively.

The data were analyzed using MSTAT-C statistical software package for variance and continued with the 5\% Least Significant Difference (LSD) test to compare the two mean values.

\section{Results and discussion}

\section{Leaf area index}

The leaf area index (LAI) of the genotypes tested was different in each shading environment (Table 1). In general, shading treatment resulted in a reduction of LAI at each observation age, as indicated by shading/non-shading ratio of the mean of all genotypes. At 28 days after planting (DAP), the LAI means were 0.85 and 0.79 $\mathrm{mg} / \mathrm{m}^{2} /$ day in non-shading and shading condition, respectively. Not all genotypes showed LAI reduction due to shading, for instance, Argopuro consistently increased LAI of $15 \%, 31 \%$, and $3 \%$ at 28,42 , and 56 DAP, respectively. Panderman also increased LAI of $38 \%$ and $5 \%$ at 28 and 42 DAP, respectively. These data indicated that at 28 and 42 DAP, there was no effect of shading on LAI conditions of these two genotypes (Argopuro and Panderman). In general, the LAI of each genotype as well as the mean of all genotypes increased with the plant ages (28 - 56 DAP) in both nonshading and shading conditions.

Table 1. Leaf area index (LAI) and S/NS ratio of seven soybean genotypes in the shading (S) and non-shading (NS) conditions at three plant ages

\begin{tabular}{|c|c|c|c|c|c|c|c|c|c|}
\hline \multirow{4}{*}{ Genotypes } & \multicolumn{9}{|c|}{ Leaf area index (LAI) at plant ages } \\
\hline & \multicolumn{3}{|c|}{28 days after planting } & \multicolumn{3}{|c|}{42 days after planting } & \multicolumn{3}{|c|}{56 days after planting } \\
\hline & $\begin{array}{c}\text { Non- } \\
\text { shading }\end{array}$ & Shading & $\begin{array}{l}\text { S/NS } \\
\text { ratio* }\end{array}$ & $\begin{array}{c}\text { Non- } \\
\text { shading }\end{array}$ & Shading & $\begin{array}{l}\text { S/NS } \\
\text { ratio }\end{array}$ & $\begin{array}{c}\text { Non- } \\
\text { shading }\end{array}$ & Shading & $\begin{array}{l}\text { S/NS } \\
\text { ratio }\end{array}$ \\
\hline & \multicolumn{2}{|c|}{$\left(\mathrm{mg} / \mathrm{m}^{2} / \mathrm{day}\right)$} & $(\%)$ & \multicolumn{2}{|c|}{$\left(\mathrm{mg} / \mathrm{m}^{2} / \mathrm{day}\right)$} & $(\%)$ & \multicolumn{2}{|c|}{$\left(\mathrm{mg} / \mathrm{m}^{2} / \mathrm{day}\right)$} & $(\%)$ \\
\hline Argopuro & 0.67 ef & $0.77 \mathrm{~cd}$ & 115 & $1.37 \mathrm{i}$ & $1.79 \mathrm{ef}$ & 131 & $1.98 \mathrm{gh}$ & $2.04 \mathrm{fg}$ & 103 \\
\hline Dena 1 & $1.08 \mathrm{a}$ & $0.76 \mathrm{cde}$ & 70 & $2.46 \mathrm{a}$ & $1.78 \mathrm{ef}$ & 72 & $2.91 \mathrm{a}$ & $2.85 \mathrm{ab}$ & 98 \\
\hline Dena 2 & $1.06 \mathrm{ab}$ & $1.02 \mathrm{ab}$ & 96 & $2.06 \mathrm{~b}$ & $1.87 \mathrm{de}$ & 91 & $2.48 \mathrm{~cd}$ & $2.53 \mathrm{c}$ & 102 \\
\hline Dena 3 & $0.73 \mathrm{de}$ & $0.46 \mathrm{~g}$ & 63 & $1.88 \mathrm{cde}$ & $1.13 \mathrm{j}$ & 60 & $2.35 \mathrm{~d}$ & $1.56 \mathrm{j}$ & 66 \\
\hline Grobogan & $1.05 \mathrm{ab}$ & $0.98 \mathrm{~b}$ & 93 & $1.95 \mathrm{bcd}$ & $1.87 \mathrm{de}$ & 96 & $2.20 \mathrm{e}$ & $1.78 \mathrm{i}$ & 81 \\
\hline Karat 13 & $0.75 \mathrm{de}$ & $0.70 \mathrm{def}$ & 93 & $2.02 \mathrm{bc}$ & $1.68 \mathrm{fg}$ & 83 & $2.72 \mathrm{~b}$ & $2.14 \mathrm{ef}$ & 79 \\
\hline Panderman & $0.61 \mathrm{f}$ & $0.84 \mathrm{c}$ & 138 & $1.52 \mathrm{~h}$ & $1.59 \mathrm{gh}$ & 105 & $1.86 \mathrm{hi}$ & $1.84 \mathrm{hi}$ & 99 \\
\hline Mean & 0.85 & 0.79 & 95 & 1.89 & 1.67 & 91 & 2.36 & 2.11 & 90 \\
\hline $\mathrm{SD}^{* *}$ & 0.20 & 0.19 & 25.3 & 0.36 & 0.26 & 22.9 & 0.38 & 0.45 & 14.3 \\
\hline
\end{tabular}

$* \mathrm{~S} / \mathrm{NS}$ ratio $=$ shading/non-shading ratio. $* * \mathrm{SD}=$ standard deviation 
Shading caused changes in shading/non-shading ratio of LAI of each soybean genotype. The shading/non-shading ratio of LAI means of 7 genotypes in each plant age were $95 \%, 91 \%$, and $90 \%$ at 28,42 , and 56 DAP, respectively. These data indicated that in this research shading reduced the LAI. This was agree with that of reported by Su et al. (2014) that the LAI of shading soybean plants was reduced by $71.0 \%$ in maizesoybean intercropping compared to monocultured soybean crops.

The pattern of changes of shading/non-shading ratio of LAI of each soybean genotype is shown in Figure 1. Dena 1, Dena 2 and Dena 3 which are considered tolerant to shading, in this study showed a reduction of LAI in the shading condition less than $100 \%$. Argopuro and Panderman varieties did not show negative effect of shading on LAI, indicated these varieties tolerant to shading based on LAI shading/nonshading ratio.

Increased of LAI in each variety or genotype is as an effort of the plants to increase light capture through increasing leaf area in shading conditions. Leaf area index is the ratio of the leaf surface to the land area where the plant grows to the leaf area as its basic component, which contributes to light interception of the entire plant canopy (Evans, 2013; Zhu et al., 2010).

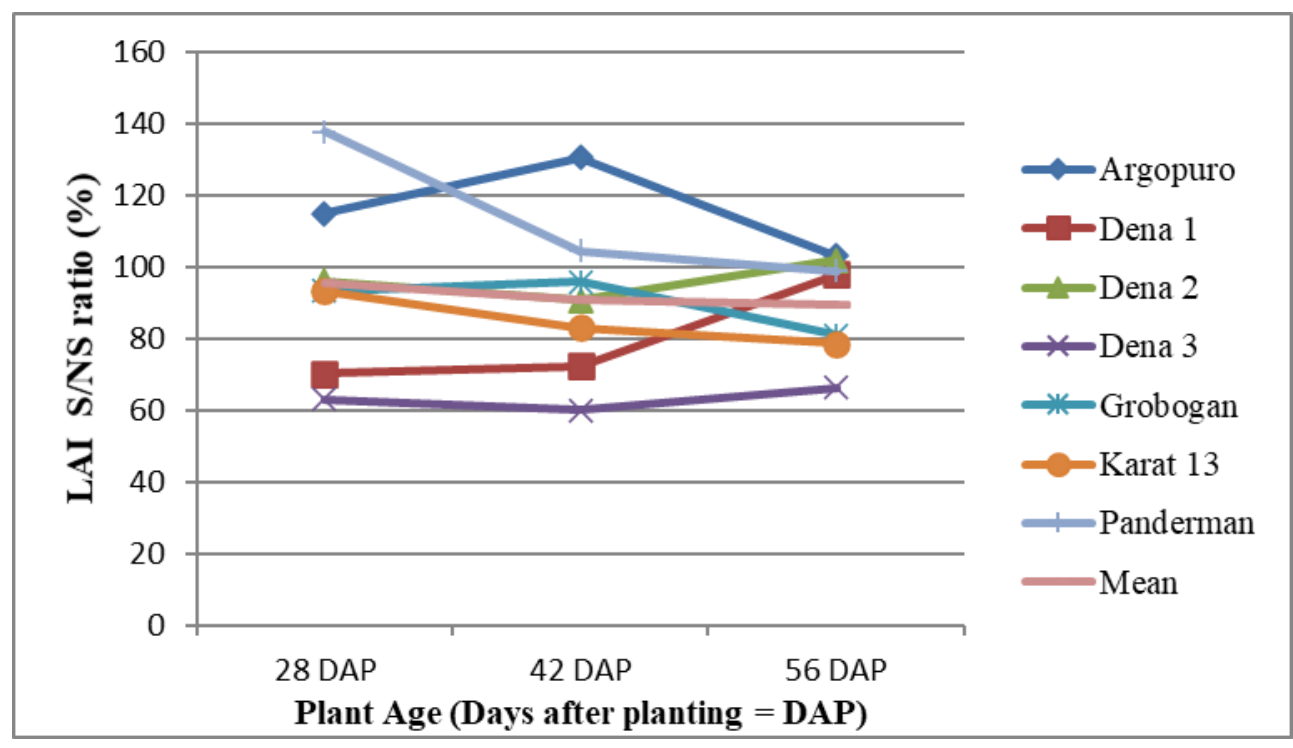

Figure 1. Shading/Non-shading ratio on leaf area index (LAI) of seven soybean genotypes at three different plant ages

\section{Leaf area specific}

The specific leaf area (SLA) of soybean genotypes tested was different in the two shading environments (Table 2). Shading resulted in an increase in SLA of each genotype and the means of 7 genotypes at each observation age. At 28 DAP, the SLA means were 182.0 and $261.6 \mathrm{~cm}^{2} / \mathrm{g}$ in non-shading and shading conditions, respectively. The SLA increased as plant grew older, namely at 56 DAP, the SLA means were 361.5 and $428.1 \mathrm{~cm}^{2} / \mathrm{g}$ in non-shading and shading conditions, respectively. Overall, shading caused an increase in SLA at various plant ages (Table 2).

The rate of reduction or stress intensity of SLA means of 7 genotypes in each plant age ranged from $18.41 \%$ at 56 DAP to $49.17 \%$ at 28 DAP (Table 2), indicated that as 
plants grew up, the leaves were less sensitive to shading effect. These pattern of SLA stress intensity of soybean genotypes at various ages of observation is presented in Figure 2. Almost all of 7 genotypes showed a decreased in SLA stress intensity values as plants grew up, except Grobogan variety that showed an increase value at 56 DAP (Fig. 2).

Table 2. Specific leaf area (SLA) and S/NS ratio of seven soybean genotypes in the shading (S) and non-shading (NS) conditions at three plant ages

\begin{tabular}{|c|c|c|c|c|c|c|c|c|c|}
\hline \multirow{4}{*}{ Genotypes } & \multicolumn{9}{|c|}{ Specific leaf area $\left(\mathrm{cm}^{2} / \mathrm{g}\right)$ at plant ages } \\
\hline & \multicolumn{3}{|c|}{28 days after planting } & \multicolumn{3}{|c|}{42 days after planting } & \multicolumn{3}{|c|}{56 days after planting } \\
\hline & $\begin{array}{c}\text { Non- } \\
\text { shading }\end{array}$ & Shading & $\begin{array}{c}\text { S/NS } \\
\text { ratio* }\end{array}$ & $\begin{array}{c}\text { Non- } \\
\text { shading }\end{array}$ & Shading & $\begin{array}{l}\text { S/NS } \\
\text { ratio }\end{array}$ & $\begin{array}{c}\text { Non- } \\
\text { shading }\end{array}$ & Shading & $\begin{array}{l}\text { S/NS } \\
\text { ratio }\end{array}$ \\
\hline & \multicolumn{2}{|c|}{$(\mathrm{mg} / \mathrm{m} 2 /$ day $)$} & $(\%)$ & \multicolumn{2}{|c|}{$(\mathrm{mg} / \mathrm{m} 2 /$ day $)$} & $(\%)$ & \multicolumn{2}{|c|}{$(\mathrm{mg} / \mathrm{m} 2 /$ day $)$} & $(\%)$ \\
\hline Argopuro & 180 ef & $262 \mathrm{bcd}$ & 146 & $137 \mathrm{fg}$ & $179 \mathrm{~b}$ & 131 & 346 de & $427 \mathrm{abc}$ & 123 \\
\hline Dena 1 & 205 e & $250 \mathrm{~d}$ & 122 & $162 \mathrm{~cd}$ & 196 a & 121 & $425 \mathrm{bc}$ & $446 \mathrm{ab}$ & 105 \\
\hline Dena 2 & 193 ef & 298 a & 154 & $150 \mathrm{de}$ & $194 \mathrm{a}$ & 129 & $409 \mathrm{c}$ & $440 \mathrm{ab}$ & 107 \\
\hline Dena 3 & $170 \mathrm{f}$ & 199 ef & 129 & $128 \mathrm{~g}$ & $172 \mathrm{bc}$ & 134 & 336 ef & $435 \mathrm{ab}$ & 129 \\
\hline Grobogan & $179 \mathrm{f}$ & $259 \mathrm{~cd}$ & 145 & $133 \mathrm{~g}$ & $169 \mathrm{bc}$ & 127 & $319 \mathrm{f}$ & $436 \mathrm{ab}$ & 137 \\
\hline Karat 13 & $175 \mathrm{f}$ & $281 \mathrm{abc}$ & 160 & $134 \mathrm{fg}$ & $175 \mathrm{~b}$ & 130 & 331 ef & $362 \mathrm{~d}$ & 109 \\
\hline Panderman & $172 \mathrm{f}$ & $286 \mathrm{ab}$ & 166 & 146 ef & $193 \mathrm{a}$ & 132 & $363 \mathrm{~d}$ & $451 \mathrm{a}$ & 124 \\
\hline Mean & 182.0 & 261.6 & 146 & 141.5 & 182.5 & 129 & 361.5 & 428.1 & 119 \\
\hline $\mathrm{SD}^{* *}$ & 12.41 & 26.25 & 16.02 & 11.97 & 11.32 & 4.36 & 40.66 & 30.23 & 12.21 \\
\hline
\end{tabular}

*S/NS ratio $=$ shading/non-shading ratio. $* * \mathrm{SD}=$ standard deviation

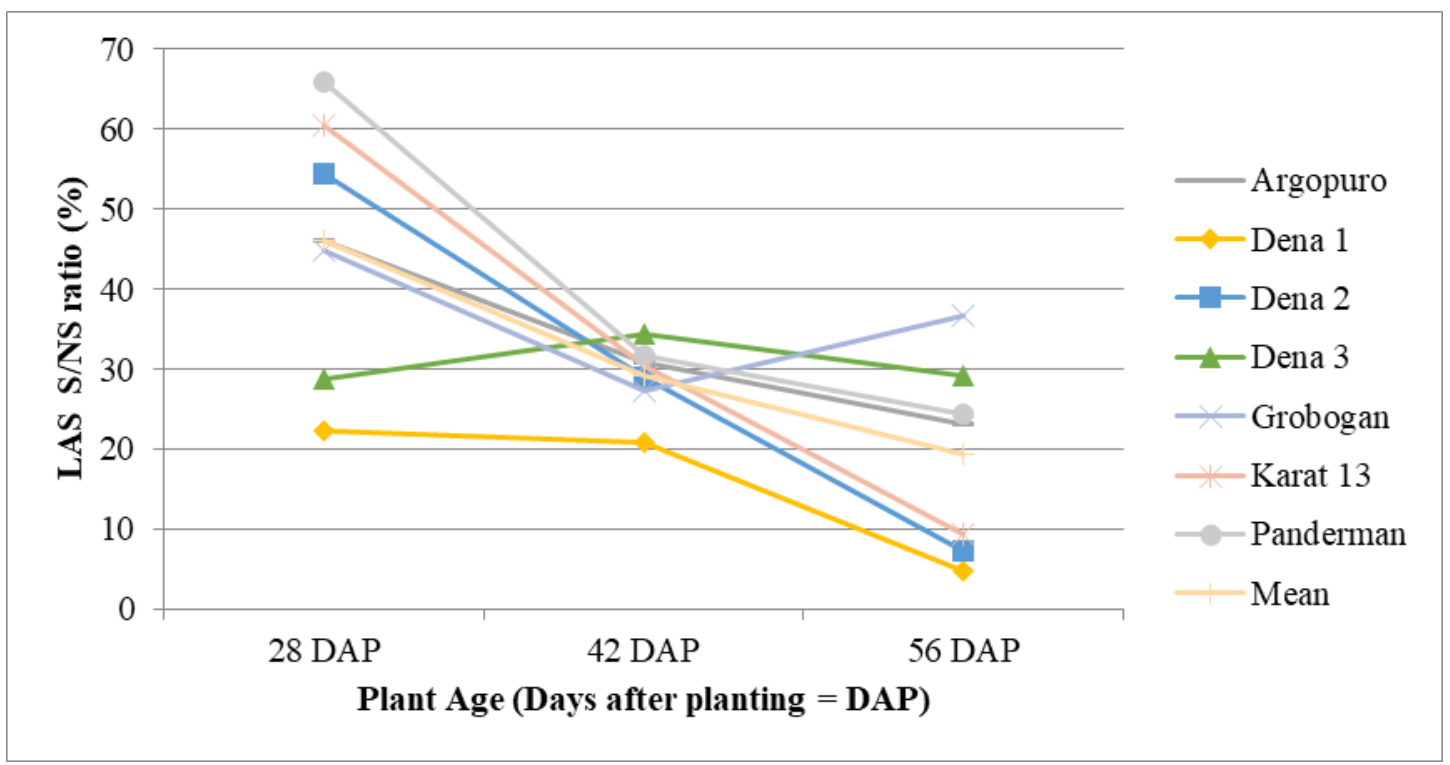

Figure 2. Shading/Non-shading ratio on specific leaf area (SLA) of seven soybean genotypes at three different plant ages

\section{Leaf area ratio}

The leaf area ratio (LAR) is the ratio between the photosynthetic organs (leaf area) and the photosynthetic product (total dry weight). The higher the LAR value, the greater the photosynthetic product used for the growth of the photosynthetic organ. LAR of 
soybean genotypes tested were different in each shading environment. Shading resulted in an increase in LAR of each genotype and the means of 7 genotypes. The highest increase in LAR value occurred at age 28 DAP, followed by age 42 and age 56 DAP i.e. $44.01 \%, 27.25 \%$, and $13.77 \%$, respectively. In the vegetative phase (aged 28 DAP), there was a sharp increase in LAR values (Table 3).

The highest changes in LAR value occurred at age 28 DAP, followed by age 42 and age 56 DAP $44.01 \%, 27.25 \%$, and $13.77 \%$, respectively (Table 3). In the vegetative phase (aged 14 and 28 DAP), there was a sharp increase in LAR values. The pattern of LAR stress intensity of 7 soybean genotypes at various ages of observation is presented in Figure 3. All genotypes showed a decreased in LAS stress intensity values as plants grew up until 56 DAP (Fig. 3).

Table 3. Leaf area ratio (LAR) and S/NS ratio of seven soybean genotypes in the shading (S) and non-shading (NS) conditions at three plant ages

\begin{tabular}{|c|c|c|c|c|c|c|c|c|c|}
\hline \multirow{4}{*}{ Genotypes } & \multicolumn{9}{|c|}{ Leaf area ratio $(\%)$ at plant ages } \\
\hline & \multicolumn{3}{|c|}{28 days after planting } & \multicolumn{3}{|c|}{42 days after planting } & \multicolumn{3}{|c|}{56 days after planting } \\
\hline & $\begin{array}{c}\text { Non- } \\
\text { shading }\end{array}$ & Shading & $\begin{array}{l}\text { S/NS } \\
\text { ratio* }\end{array}$ & $\begin{array}{c}\text { Non- } \\
\text { shading }\end{array}$ & Shading & $\begin{array}{l}\text { S/NS } \\
\text { ratio }\end{array}$ & $\begin{array}{c}\text { Non- } \\
\text { shading }\end{array}$ & Shading & $\begin{array}{l}\text { S/NS } \\
\text { ratio }\end{array}$ \\
\hline & \multicolumn{2}{|c|}{$(\%)$} & $(\%)$ & \multicolumn{2}{|c|}{$(\%)$} & $(\%)$ & \multicolumn{2}{|c|}{$(\%)$} & $(\%)$ \\
\hline Argopuro & $115 \mathrm{fg}$ & $167 \mathrm{~cd}$ & 146 & $82 \mathrm{fg}$ & $102 \mathrm{bc}$ & 124 & 62 bcd & $66 \mathrm{fg}$ & 106 \\
\hline Dena 1 & 129 ef & $162 \mathrm{~d}$ & 125 & $93 \mathrm{de}$ & $114 \mathrm{a}$ & 123 & $61 \mathrm{cde}$ & $65 \mathrm{~b}$ & 106 \\
\hline Dena 2 & $124 \mathrm{efg}$ & $193 \mathrm{ab}$ & 155 & $83 \mathrm{fg}$ & $106 \mathrm{~b}$ & 127 & $56 \mathrm{fg}$ & $60 \mathrm{de}$ & 107 \\
\hline Dena 3 & $111 \mathrm{~g}$ & $135 \mathrm{e}$ & 121 & $80 \mathrm{gh}$ & $106 \mathrm{~b}$ & 132 & $54 \mathrm{~g}$ & $70 \mathrm{a}$ & 129 \\
\hline Grobogan & 129 ef & $173 \mathrm{~cd}$ & 134 & $73 \mathrm{~h}$ & $96 \mathrm{~cd}$ & 132 & $51 \mathrm{~h}$ & $64 \mathrm{bc}$ & 127 \\
\hline Karat 13 & 119 efg & 198 a & 167 & 88 ef & 116 a & 132 & $56 \mathrm{fg}$ & $64 \mathrm{bc}$ & 116 \\
\hline Panderman & $111 \mathrm{~g}$ & $180 \mathrm{bc}$ & 163 & 85 efg & $105 \mathrm{~b}$ & 123 & $58 \mathrm{ef}$ & $62 \mathrm{bcd}$ & 107 \\
\hline Mean & 119.8 & 172.5 & 144 & 83.5 & 106.3 & 127 & 55.4 & 63.0 & 114 \\
\hline $\mathrm{SD}^{* *}$ & 8.07 & 21.20 & 18.12 & 6.21 & 6.77 & 4.36 & 3.98 & 3.19 & 10.12 \\
\hline
\end{tabular}

$* \mathrm{~S} / \mathrm{NS}$ ratio $=$ shading/non-shading ratio. $* * \mathrm{SD}=$ standard deviation

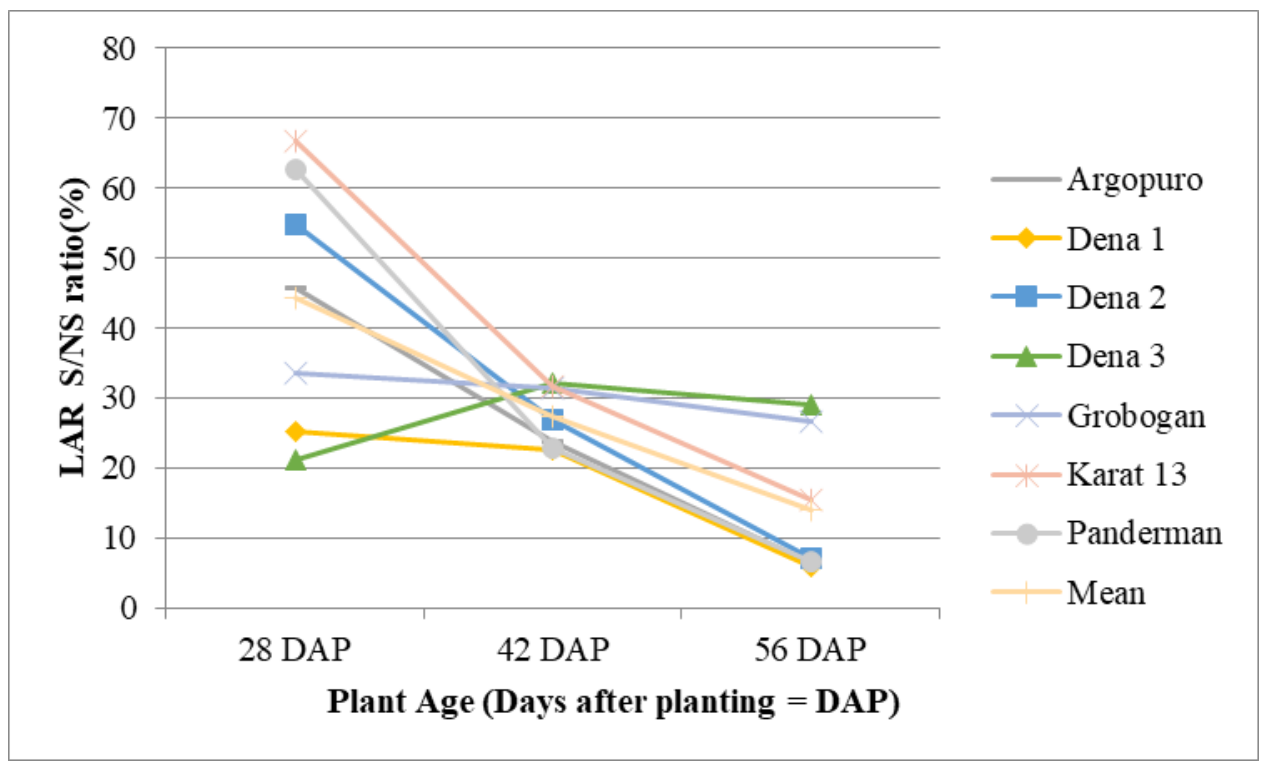

Figure 3. Shading/non-shading ratio on leaf area ratio (LAR) of seven soybean genotypes at three different plant ages 


\section{Net assimilation rate}

Net assimilation rate (NAR) is the result of net assimilation of the unity of leaf area of time. The NAR value shows a decrease with the increase of plant age. Shading resulted in a decrease in NAR of each genotype and the means of 7 genotypes (Table 4). At 28 days after planting (DAP), the NAR means were 16.53 and $10.65 \mathrm{mg} / \mathrm{m}^{2} /$ day in non-shading and shading conditions, respectively. The NAR values decreased as plant grew older (42 and 56 DAP). At 56 DAP the NAR means were 7.50 and $5.94 \mathrm{mg} / \mathrm{m}^{2} /$ day in non-shading and shading conditions, respectively or the decreased were $55 \%$ and $46 \%$ in non-shading and shading conditions, respectively compared to NAR values at 28 DAP.

Shading caused changes in the NAR or NAR stress intensity of each soybean genotype. The highest mean stress intensity of net assimilation rate (NAR) of seven soybean genotypes due to shading condition at various plant ages occurred at age 28 DAP (35.59\%), followed by $24.03 \%$ and $20.80 \%$ at ages of 42 and age 56 DAP, respectively (Table 4). Dena 1, Dena 2 and Dena 3 genotypes which are considered tolerant to shading, in this study showed NAR stress intensity at 28 DAP of $34.57 \%$, $39.32 \%$, and $36.35 \%$ which are above the average $(31.69 \%)$. Grobogan 13 genotype showed the lowest NAR stress intensity of $21.88 \%$ followed Karat 13 genotype (31.69\%). However, at age 56 DAP, Dena 1, Grobogan and Panderman genotypes showed NAR stress intensity of $16.80 \%, 12.01 \%$, and $14.93 \%$ which are below the average at 56 DAP (19.95\%). These 3 genotypes indicated tolerant to shading based on NAR stress intensity at 56 DAP.

Table 4. Net assimilation rate (NAR) and stress intensity of seven soybean genotypes in the shading (S) and non-shading (NS) conditions at different plant ages

\begin{tabular}{|c|c|c|c|c|c|c|c|c|c|}
\hline \multirow{4}{*}{ Genotypes } & \multicolumn{9}{|c|}{ Net assimilation rate } \\
\hline & \multicolumn{3}{|c|}{28 days after planting } & \multicolumn{3}{|c|}{42 days after planting } & \multicolumn{3}{|c|}{56 days after planting } \\
\hline & $\begin{array}{c}\text { Non- } \\
\text { shading }\end{array}$ & Shading & $\begin{array}{l}\text { S/NS } \\
\text { ratio* }\end{array}$ & $\begin{array}{c}\text { Non- } \\
\text { shading }\end{array}$ & Shading & $\begin{array}{l}\text { S/NS } \\
\text { ratio* }\end{array}$ & $\begin{array}{c}\text { Non- } \\
\text { shading }\end{array}$ & Shading & $\begin{array}{l}\text { S/NS } \\
\text { ratio* }\end{array}$ \\
\hline & \multicolumn{2}{|c|}{$\left(\mathrm{mg} / \mathrm{m}^{2} / \mathrm{day}\right)$} & $(\%)$ & \multicolumn{2}{|c|}{$\left(\mathrm{mg} / \mathrm{m}^{2} / \mathrm{day}\right)$} & $(\%)$ & \multicolumn{2}{|c|}{$\left(\mathrm{mg} / \mathrm{m}^{2} / \mathrm{day}\right)$} & $(\%)$ \\
\hline Argopuro & $19.27 \mathrm{a}$ & $13.11 \mathrm{a}$ & 68 & $8.93 \mathrm{bc}$ & $6.29 \mathrm{c}$ & 70 & $10.14 \mathrm{a}$ & $7.25 \mathrm{a}$ & 71 \\
\hline Dena 1 & $17.81 \mathrm{a}$ & $11.65 \mathrm{~b}$ & 65 & $9.37 \mathrm{bc}$ & $7.34 \mathrm{bc}$ & 78 & 6.24 & $5.19 \mathrm{~b}$ & 83 \\
\hline Dena 2 & $17.22 \mathrm{a}$ & $10.45 \mathrm{~b}$ & 61 & $8.61 \mathrm{bc}$ & $6.81 \mathrm{c}$ & 79 & $9.13 \mathrm{a}$ & $7.30 \mathrm{a}$ & 80 \\
\hline Dena 3 & $15.79 \mathrm{ab}$ & $10.05 \mathrm{~b}$ & 64 & $13.88 \mathrm{a}$ & $9.40 \mathrm{~b}$ & 68 & $5.48 \mathrm{c}$ & 4.26 & 78 \\
\hline Grobogan & $12.35 \mathrm{c}$ & $9.65 \mathrm{bc}$ & 78 & $16.85 \mathrm{a}$ & $12.61 \mathrm{a}$ & 75 & $7.56 \mathrm{ab}$ & $6.65 \mathrm{a}$ & 88 \\
\hline Karat 13 & $16.32 \mathrm{ab}$ & $12.62 \mathrm{~b}$ & 77 & $13.34 \mathrm{ab}$ & $10.40 \mathrm{ab}$ & 78 & $9.54 \mathrm{a}$ & $7.15 \mathrm{a}$ & 75 \\
\hline Panderman & $16.97 \mathrm{ab}$ & $11.02 \mathrm{~b}$ & 65 & $12.50 \mathrm{~b}$ & $9.60 \mathrm{~b}$ & 77 & $4.41 \mathrm{c}$ & $3.75 \mathrm{bc}$ & 85 \\
\hline Mean & 16.53 & 11.22 & 68 & 11.93 & 8.92 & 75 & 7.50 & 5.94 & 79 \\
\hline $\mathrm{SD} * *$ & 2.15 & 1.30 & 6.80 & 3.08 & 2.25 & 4.36 & 2.20 & 1.51 & 5.82 \\
\hline
\end{tabular}

$* \mathrm{~S} / \mathrm{NS}$ ratio $=$ shading/non-shading ratio. $* * \mathrm{SD}=$ standard deviation

The pattern of changes of NAR stress intensity of each genotype at three ages of observation is presented in Figure 4. Almost all of 7 genotypes showed a decreased in LAS stress intensity values as plants grew up, except Dena1 that showed an increase value at 56 DAP. This pattern indicated that as plants grew up, the leaves were less sensitive to shading effect. 


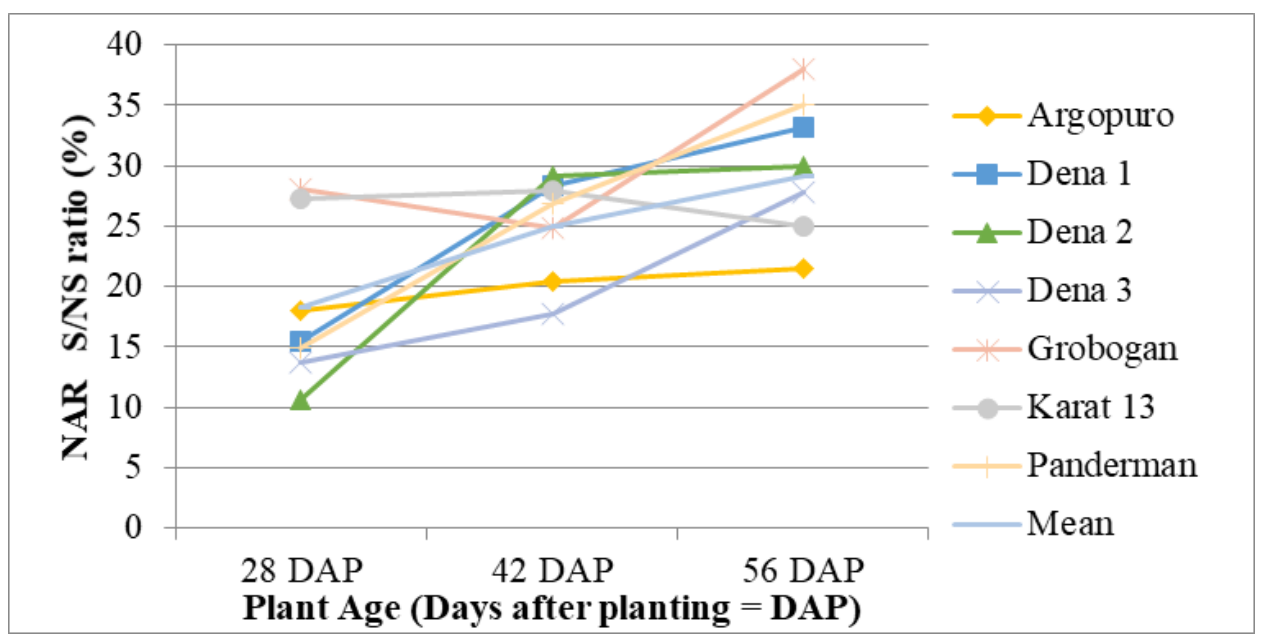

Figure 4. Shading/non-shading ratio on net assimilation rate (NAR) of seven soybean genotypes at three different plant ages

\section{Plant growth rate}

The plant growth rate (PGR) of each genotype showed differences in each shading environment. Shading resulted in a decrease in PGR of each genotype and the means of 7 genotypes (Table 5). At 28 DAP, the PGR means were 0.71 and $0.41 \mathrm{~g} / \mathrm{cm}^{2} /$ day in non-shading and shading conditions, respectively. The highest PGR values occurred at 42 DAP then decreased as plant grew older (56 DAP). At 42 DAP the PGR means were 1.31 and $0.99 \mathrm{~g} / \mathrm{cm}^{2} /$ day in non-shading and shading conditions, respectively. At 56 DAP the PGR means were 1.08 and $0.80 \mathrm{~g} / \mathrm{cm}^{2} /$ day in non-shading and shading conditions, respectively or the decreased were $22 \%$ and $14 \%$ in non-shading and shading conditions, respectively, compared to PGR values at 42 DAP.

Table 5. Plant growth rate and stress intensity of seven soybean genotypes in the shading $(S)$ and non-shading (NS) conditions at various plant ages

\begin{tabular}{|c|c|c|c|c|c|c|c|c|c|}
\hline \multirow{4}{*}{ Genotypes } & \multicolumn{9}{|c|}{ Plant growth rate } \\
\hline & \multicolumn{3}{|c|}{28 days after planting } & \multicolumn{3}{|c|}{42 days after planting } & \multicolumn{3}{|c|}{56 days after planting } \\
\hline & $\begin{array}{c}\text { Non- } \\
\text { shading }\end{array}$ & Shading & $\begin{array}{c}\text { S/NS } \\
\text { ratio* }\end{array}$ & $\begin{array}{c}\text { Non- } \\
\text { shading }\end{array}$ & Shading & $\begin{array}{c}\text { S/NS } \\
\text { ratio* }\end{array}$ & $\begin{array}{c}\text { Non- } \\
\text { shading }\end{array}$ & Shading & $\begin{array}{c}\text { S/NS } \\
\text { ratio* }\end{array}$ \\
\hline & \multicolumn{2}{|c|}{ (g/cm²/day) } & $(\%)$ & \multicolumn{2}{|c|}{ (g/cm²/day) } & $(\%)$ & \multicolumn{2}{|c|}{ (g/cm²/day) } & $(\%)$ \\
\hline Argopuro & $0.62 \mathrm{~b}$ & $0.30 \mathrm{~b}$ & 48 & $0.73 \mathrm{c}$ & $0.68 \mathrm{bc}$ & 93 & $1.19 \mathrm{a}$ & $0.72 b$ & 61 \\
\hline Dena 1 & $0.92 \mathrm{a}$ & $0.46 \mathrm{a}$ & 50 & $1.36 \mathrm{~b}$ & $0.96 \mathrm{~b}$ & 71 & $1.09 \mathrm{~b}$ & $1.02 \mathrm{a}$ & 94 \\
\hline Dena 2 & $0.92 \mathrm{a}$ & $0.55 \mathrm{a}$ & 60 & $1.05 \mathrm{bc}$ & $1.10 \mathrm{~b}$ & 105 & $1.36 \mathrm{a}$ & $0.95 \mathrm{a}$ & 70 \\
\hline Dena 3 & $0.64 \mathrm{~b}$ & $0.25 \mathrm{bc}$ & 39 & $1.47 \mathrm{~b}$ & $0.71 \mathrm{bc}$ & 48 & $0.77 \mathrm{c}$ & $0.48 \mathrm{~d}$ & 62 \\
\hline Grobogan & $0.70 \mathrm{~b}$ & $0.52 \mathrm{a}$ & 74 & $1.95 \mathrm{a}$ & $1.39 \mathrm{a}$ & 71 & $1.00 \mathrm{~b}$ & $0.69 \mathrm{bc}$ & 69 \\
\hline Karat 13 & $0.63 \mathrm{~b}$ & $0.33 \mathrm{~b}$ & 52 & $1.53 \mathrm{~b}$ & $1.18 \mathrm{a}$ & 77 & $1.15 \mathrm{ab}$ & $0.91 \mathrm{a}$ & 79 \\
\hline Panderman & $0.52 \mathrm{~b}$ & $0.47 \mathrm{a}$ & 90 & $1.10 \mathrm{bc}$ & $0.91 \mathrm{~b}$ & 83 & $0.99 \mathrm{~b}$ & $0.83 \mathrm{~b}$ & 84 \\
\hline Mean & 0.71 & 0.41 & 59 & 1.31 & 0.99 & 78 & 1.08 & 0.80 & 74 \\
\hline $\mathrm{SD}^{* *}$ & 0.15 & 0.12 & 17.58 & 0.39 & 0.25 & 18.03 & 0.19 & 0.18 & 12.02 \\
\hline
\end{tabular}

$* \mathrm{~S} / \mathrm{NS}$ ratio $=$ shading/non-shading ratio. $\mathrm{SD}=$ standard deviation

Plant growth rate (PGR) is the rate of plant weight gain per unit land area per unit time (Gardner et al., 1985). Shading caused changes in the PGR or PGR S/NS ratio of 
each soybean genotype. The highest mean stress intensity of PGR of seven soybean genotypes due to shading condition at various plant ages occurred at age 28 DAP (33.37\%), followed by $32.23 \%$ and $24.33 \%$ at ages of 42 and age 56 DAP, respectively (Table 5). Dena 1, Dena 2 and Dena 3 genotypes which are considered tolerant to shading, in this study at 28 DAP showed PGR stress intensity of $28.26 \%, 18.48 \%$, and $29.69 \%$ which are below the average (33.37\%). Dena 2 genotype showed the lowest PGR stress intensity of $18.48 \%$ followed Dena 1 genotype $(28.26 \%)$. However at age 56 DAP, Dena 1 genotype showed the lowest PGR stress intensity of 6\%, followed by Panderman of $16 \%$ which are below the average at 56 DAP (24\%). These two genotype indicated tolerant to shading based on PGR stress intensity at 56 DAP.

\section{Seed yield}

Shading resulted in decreasing of seed yield/ha average of 7 genotypes by $36.3 \%$. The stress intensity on seed yield due to shading varied for each genotype, by which the higest $(60 \%)$ showed by Dena 2 variety, while the lowest $(26 \%)$ showed by Dena 1 variety. The stress intensity on 100 seed weight due to shading showed that the highest $(50.6 \%)$ was Grobogan 3 variety, while the lowest $(7.3 \%)$ showed by Dena 2 variety (Table 6). In the vegetative phase, plant growth is characterized by the formation of vegetative organs such as leaves, stems and roots (Purcell et al., 2014). Su et al. (2014) reported that in maize-soybean intercropping compared to monocultured soybean crops, the shading effect of maize on soybean caused the seed yield decreased by $32.8 \%$. (Khalid et al., 2019) reported that in maize-soybean intercropping, the seed-yield of $25 \%$ shading (T75) was $88 \%$ of and non-shading (T0) yield. They suggested that in intercropping planting pattern, the maximum shade density ranges from 20 to $30 \%$ to obtain higher seed yield of soybean crop under intercropping-system. The effect of shading on soybean yields were 54.69\% lower than those in monoculture respectively, suggested that soybean plants can regulate its morphological characteristics and leaf anatomical structures under different light environments (Fan et al., 2018).

Table 6. Seed traits and their stress intensity due to shading condition

\begin{tabular}{c|c|c|c}
\hline \multirow{2}{*}{ Genotypes } & \multicolumn{3}{|c}{ Seed yield per ha } \\
\cline { 2 - 4 } & Non-Shading & Shading & S/NS ratio* \\
\cline { 2 - 4 } & \multicolumn{2}{|c}{ (ton) } \\
\hline Argopuro & $3.55 \mathrm{~b}$ & $2.34 \mathrm{e}$ & 66 \\
Dena 1 & $2.06 \mathrm{f}$ & $1.52 \mathrm{~d}$ & 74 \\
Dena 2 & $2.21 \mathrm{ef}$ & $1.32 \mathrm{e}$ & 40 \\
Dena 3 & $2.14 \mathrm{c}$ & $1.42 \mathrm{i}$ & 45 \\
Grobogan & $2.59 \mathrm{~d}$ & $1.78 \mathrm{gh}$ & 69 \\
Karat 13 & $2.69 \mathrm{~h}$ & $1.68 \mathrm{~d}$ & 62 \\
Panderman & $2.21 \mathrm{a}$ & $1.08 \mathrm{~g}$ & 51 \\
\hline Mean & $\mathbf{2 . 4 9}$ & $\mathbf{1 . 5 9}$ & $\mathbf{6 3 . 7}$ \\
SD** & $\mathbf{0 . 5 2}$ & $\mathbf{0 . 4 0}$ & $\mathbf{7 . 9 2}$ \\
\hline
\end{tabular}

$* \mathrm{~S} / \mathrm{NS}$ ratio $=$ shading/non-shading ratio. $* * \mathrm{SD}=$ standard deviation

\section{Correlation of stress intensity parameters}

Correlation analysis (Table 7) showed that the plant growth rate (PGR) was significantly negatively correlated with specific leaf area (SLA) $\left(r=-0.554^{*}\right)$ but 
positively correlated with seed yield $\left(\mathrm{r}=0.978^{* *}\right)$. Leaf area ratio (LAR) showed significantly negative correlation with leaf area index (LAI) $\left(\mathrm{r}=-0.643^{* *}\right)$ but significantly postive correlation with SLA $\left(\mathrm{r}=0.656^{* *}\right)$. The increase in LAI is related to the plant's efforts to increase light acceptance through increasing leaf area. Verdelli et al. (2012) showed that an increase in light interception was followed by an increase in plant growth rate.

Table 7. Correlations values among stress intensity parameters

\begin{tabular}{c|c|c|c|c|c}
\hline Characters & LAI & SLA & LAR & NAR & PGR \\
\hline LAS & 0.016 & & & & \\
LAR & $-0.643^{* *}$ & $0.656^{* *}$ & & & \\
NAR & 0.089 & 0.279 & 0.214 & & \\
PGR & 0.122 & $-0.554^{*}$ & -0.45 & 0.435 & \\
Seed yield & 0.076 & $-0.658^{* *}$ & $-0.514 *$ & 0.240 & $0.978^{* *}$ \\
\hline
\end{tabular}

$*$ and $* *$ are significantly different at $5 \%$ and $1 \%$ levels, respectively

The reduction in SLA is associated with an increase in leaf thickness, and is determined by the thickness of the constituent cell tissues, such as upper and lower epidermal cells, and palisade tissue. At low light intensity the plants were only able to develop one layer of palisade tissue while at high light intensity the plants were able to develop two layers of palisade tissue (Sundari et al., 2008). Palisade tissue contains a lot of chloroplasts which are very important in increasing the efficiency of photosynthesis. Shading causes changes in the quantity of light received by soybean plants to decrease, so that it affects the parameters of the analysis of plant growth genotypes. The response of soybean genotypes to shading was different, which was indicated by differences in the growth analysis parameters of each genotype in their respective environments. Lakshmanakumar and Guru (2014) argued that plant growth rate, relative growth rate, net assimilation rate, leaf area index, and leaf specific weight were affected by shading.

Specific leaf area (SLA) is the ratio of leaf area to leaf dry weight, which shows the level of leaf thickness and the efficiency of the leaf area formation process and the greater the SLA value, the thinner the leaf in question. Shading causes an increase in the SLA value which means a decrease in the level of leaf thickness. The results of research by Aragão et al. (2014) showed that the thickness of the leaf tissue was influenced by light intensity, which at high light intensity, the leaf tissue was thicker than at low light intensity. Costa et al. (2010) also reported that leaf thickness increased in plants grown in full sunlight, greater expansion of the abaxial epidermis and spongy parenchyma than in shading grown plants.

The pattern of changes in the SLA due to shading was different (Fig. 3). In general, shading increased the SLA of soybean genotypes at different rates of increase between observation times. The increase in SLA indicated that the increase in leaf area was greater than the increase in leaf dry weight. Srikrishnah et al. (2012) stated that plants grown under $50 \%$ and $70 \%$ shading levels produced higher leaf area and biomass than plants grown under $80 \%$ shading. Leaf area is a determining factor in the interception mechanism of light radiation and water, and energy exchange (Peksen, 2007). Thus, it can be stated that increasing SLA is a plant strategy to increase the ability to compete in the shading for light. Devkota and Jha (2010), Gobbi et al. (2011) and Matsoukis et al. (2015) reported that plants grown under shading produced higher SLA than plants grown under full light intensity. Under the shading, the plants have thinner leaves, 
reduced distribution of photosynthate to each cell, so that the cells making up the leaf blade experience a reduction in leaf thickness (Maghfiroh, 2006).

Dena 1 was a soybean genotype that showed relatively stable increase in the LAS value among observation times, except for the age of 56 DAP. The increase in LAS values at age 14, 28, 42 and 56 DAP were $23.43 \%, 22.30 \%, 20.75 \%$, and $4.84 \%$, respectively, which means that the leaf thickness level of Dena 1 variety has not changed much in the presence of shading treatment suggesting that Dena 1 variety was adaptive to shading.

The 50\% shading increased the leaf area ratio (LAR) value of the soybean genotype (Table 3), indicated that the photosynthate yield in the shading was mostly allocated for the formation of photosynthetic organs (leaves). Corre (1983), reported that shading caused an increase in leaf area ratio (LAR) through a reduction in leaf specific weight (LSW) which was associated with a reduction in leaf thickness. The higher the LAR value, the higher the proportion of leaf area which reflects the large area of photosynthesis. According to Costa et al. (2010), increased LAR under shading indicates that plants require a larger leaf area to produce one gram of dry matter than plants that are without shading. Increasing the LAR value of soybean varieties Dena 1 at several times of observation showed stability, with an increase in LAR values of $23.98 \%$ (at 14 DAP), $25.27 \%$ (at 28 DAP), and $22.65 \%$ (at 42 DAP), while increased in LAR values only reached $5.93 \%$ at the age of 56 DAP. The increase in LAR in the other six genotypes showed instability which showed that Dena 1 was a soybean genotype that was able to adapt to a shading environment.

The net assimilation rate (NAR) values in the initial period of growth was low, both in the treatment without shading or with 50\% shading, then increased in the following period. Öztürk et al. (2014), suggested that plants grown under shading produced low NAR in the initial period of growth and high in the final period of their growth. The reduction in $\mathrm{LAB}$ was due to the reduced light received by the leaves because the shading caused the disruption of the photosynthesis process with light as the main energy source in the photosynthesis or assimilation process. The disruption of the photosynthesis process resulted in reduced photosynthate per unit leaf area per unit time. The results of other studies showed that the soybean intercropped with Populus deltoides x nigra varieties DN-177, Acer saccharinum Marsh., and Juglans nigra L. experienced a reduction in net assimilation by $53.1 \%, 67.5 \%$, and $46.5 \%$ respectively, compared to monoculture soybeans (Peng et al., 2015).

The plant growth rate (PGR) of soybean genotype showed differences in each shading environment (Fig. 5). In an environment without shading, Grobogan variety which was classified as early maturity had high PGR at the age of 42 DAP, while Karat 13 which was in the late maturity showed high PGR at 56 DAP. The shaded of Grobogan variety still showed high PGR at the age of 42 DAP, however the PGR decreased with increased plant age. Shaded of Dena 1 and Dena 2 varieties were still able to show high PGR values at the age of 56 DAP. The difference in PGR among genotypes may be due to differences in age among genotypes and also the level of sensitivity of each genotype to different shading stresses. The difference in plant age, caused different growth phases. The growth phase determined the PGR by which maximum PGR occurred in the pod filling phase because the leaf area was maximally developed (Mondal et al., 2012).

Grobogan is classified as an early maturity genotype and susceptible to shading, so it is not able to maintain the PGR in the longer shading stress conditions. Dena 1 and 
Dena 2 varieties were classified as medium maturity and adaptive to shading, so they were able to maintain and even increase PGR in longer shading conditions. Dena 1 and Dena 2 varieties were more efficient in utilizing limited light intensity, compared to the other five genotypes. During its life cycle the plant experiences shading, although only for a short period of time (Valladares and Niinemets, 2008). Active photosynthetic radiation stimulates the light reaction in the photosynthetic process, and is considered to be the main energy source for photosynthesis in shading-tolerant plants (Valladares and Niinemets, 2008; Gommers et al., 2013), and the R:FR ratio is considered to be the most important light factor.

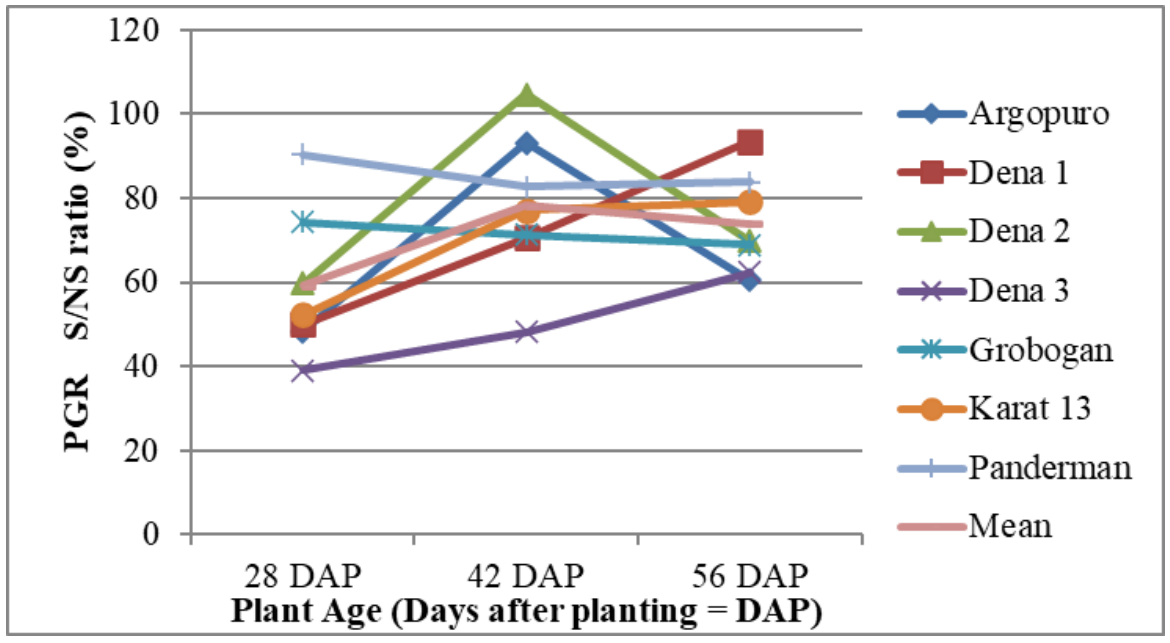

Figure 5. Shading/non-shading ratio on plant growth rates $(P G R)$ of seven soybean genotypes at three different plant ages

Plants face shading by implementing two suitable strategies, namely: tolerance and avoidance of shading (Gommers et al., 2013). A tolerant response to shading is achieved through optimization of light capture and utilization, including increased chlorophyll content, specific leaf area, photosystem II:I ratio, and decreased chlorophyll a:b ratio, all of which lead to increased leaf carbon content (Valladares and Niinemets, 2008; Niinemets, 2010; Valladares et al. 2007). Under shading conditions, plants developed relatively larger leaves at the expense of leaf weight per unit area and increased accumulated chlorophyll content per unit leaf weight. This provides a greater opportunity for plants to capture light (Valladares and Niinemets, 2008; Evans et al., 2009; Niinemets, 2010; Casal, 2013; Gommers et al., 2013).

The genotypes used in the study are still grown by farmers until recently. Seed production is conducted by ILETRI to support the accelerated program of increasing soybean production. In 2020, a total of $10,500 \mathrm{~kg}$ of Foundation Seeds (FS) class soybeans were produced, respectively, from 9 popular varieties and several other varieties. The figure below shows a total of $16,724 \mathrm{~kg}$ of seeds FS were distributed to the seed growers around the country (Balitkabi, 2020).

\section{Conclusion}

Soybean genotypes responses to shading were different. Shading reduced leaf area index (LAI), net assimilation rate (NAR), and plant growth rate (PGR), however it 
increased specific leaf area (SLA) and leaf area ratio (LAR). At age 56 DAP, Dena 1 genotype showed the lowest PGR stress intensity at $6 \%$, followed by Panderman at $16 \%$ which are below the average of PGR genotypes stress intensity at $24 \%$. The PGR had significantly positive correlation with seed yield. Shading resulted in decreasing of seed yield/ha and 100 seed weight as compared to the average of 7 genotypes by $32 \%$ and $24.7 \%$, respectively. Dena 1 showed the most tolerant to shading. In the future, it is necessary to investigate the economic feasibility of soybean farming under shading, both with maize and young plantation intercrops.

Acknowledgments. The authors would like to acknowledge the Director General of the Indonesian Agency for Agricultural Research and Development (IAARD) for the research funding, to the Head of ILETRI who have guided of this research, and to technicians for the support during the implementation this research.

\section{REFERENCES}

[1] Aragão, D. S., Lunz, A., de Oliveira, L. C., Fermino Jr., P. C. P. (2014): Effect of shading on leaf anatomy of young plants of Andiroba (Carapa guianensis Aubl.). - Revista Árvore 38(4): 631-639. DOI: 10.1590/S0100-67622014000400006.

[2] Balitkabi, L. T. (2020): Hasil Utama Penelitian Tanaman AnekaKacang dan Umbi. Balai Penelitian Tanaman Aneka Kacang dan Umbi, Malang.

[3] Casal, J. J. (2013): Photoreceptor signaling networks in plant responses to shading. Annual Review of Plant Biology 64: 403-427. DOI: 10.1146/annurev-arplant-050312120221.

[4] Corre, W. J. (1983): Growth and morphogenesis of sun and shading plants on the influence of light intensity. - Acta Botanica Neerlandica 32: 49-62.

[5] Costa, L. C. D. B., Pinto, J. E. B. P., de Castro, E. M., Alves, E., Bertolucci, S. K. V., Rosal, L. F. (2010): Effects of coloured shading netting on the vegetative development and leaf structure of Ocimum selloi. - Bragantia, Campinas 69(2): 349-359. http://www.scielo.br/pdf/brag/v69n2/12.pdf.

[6] Devkota, A., Jha, P. K. (2010): Effects of different light levels on the growth traits and yield of Centella asiatica. - Middle-East Journal of Scientific Research 5: 226-230.

[7] Evans, J. R. (2013): Improving photosynthesis. - Plant Physiology 162: 1780-1793. DOI: 10.1104/pp.113.219006.

[8] Evans, J. R., Kaldenhoff, R., Genty, B., Terashima, I. (2009): Resistances along the $\mathrm{CO}_{2}$ diffusion pathway inside leaves. - Journal of Experimental Botany 60: 2235-2248. DOI: 10.1093/jxb/erp117.

[9] Fan, Y., Chen, J., Cheng, Y., Raza, M. A., Wu, X., Wang, Z., et al. (2018): Effect of shading and light recovery on the growth, leaf structure, and photosynthetic performance of soybean in a maize-soybean relay-strip intercropping system. - PLoS ONE 13(5): 115. https://doi.org/10.1371/journal.pone.0198159.

[10] Gardner, F. P., Pearce, R. B., Mitchell, R. (1985): Physiology of Crop Plants. - The Iowa State University Press, Iowa.

[11] Gobbi, K. F., Garcia, R., Ventrella, M. C., Neto, A. F. G., Rocha, G. C. (2011): Área foliarespecífica e anatomia foliar quantitativa docapim-braquiária e do amendoimforrageiro submetidos a sombreamento. - Revista Brasileira de Zootecnia 40: 1436-1444.

[12] Gommers, C. M. M., Visser, E. J. W., Onge, K. R. S., Voesenek, L. A. C. J., Pierik, R. (2013): Shading tolerance: when growing tall is not an option. - Trends in Plant Science 18: 65-71. DOI: 10.1016/j.tplants.2012.09.008. 
[13] Gonzalez, N., Vanhaeren, H., Inzé, D. (2012): Leaf size control: complex coordination of cell division and expansion. - Trends in Plant Science 17: 332-340. DOI: 10.1016/j.tplants.2012.02.003.

[14] Harsono, H., Elisabeth, D. A. A., Muzaiyanah, S., Rianto, S. A. (2020): Soybean-maize intercropping feasibility under drought-prone area in East Java, Indonesia. - Biodiversitas 21(8): 3744-3754.

[15] Huang, W., Zhang, S. B., Liu, T. (2018): Moderate photoinhibition of photosystem II significantly affects linear electron flow in the shade-demanding plant Panax notoginiseng. - Frontier Plant Science 9: 637. Doi: 10.3389/fpls.2018.00637.

[16] Khalid, M. H. B., raza, M. A., Yu, H. Q., Sun, F. A., Zhang, Y. Y., Lu, F. Z., Si, L., Iqbal, N., Khan, I., Fu, F. L., Li, W. C. (2019): Effect of shade treatments on morphology, photosynthetic and chlorophyll fluorescence characteristics of soybeans (Glycine max L. Merr.). - Applied Ecology and Environmental Research 17(2): 2551-2569.

[17] Lakshmanakumar, P., Guru, S. K. (2014): Growth indices of yield variability in wheat (Triticum aesitivum L.) under varying degree of shadings. - Journal of Global Biosciences 3(4): 778-786.

[18] Li, L., Gan, Y. T., Bueckert, G., Warkentin, T. D. (2010): Shading, defoliation and light enrichment effects on chickpea in northern latitudes. - J. Agron. Crop Sci. 196: 220-230.

[19] Liu, B. C., Wang, Y., Li, S., Jin, L., Herbert, S. J. (2010): Soybean yield and yield component distribution across the main axis in response to light enrichment and shading under different densities. - Plant Soil Environment 56(8): 384-392.

[20] Liu, W. G., Ren, M. L., Liu, T., Du, Y. L., Zhou, T., X. M., Liu, E.... (2018): Effect of shade stress on lignin biosynthesis in soybean stems. - J. Integr. Agric. 17: 1594-1604.

[21] Maghfiroh, L. (2006): Identifikasi Genotip Kedelai (Glycine max (L).) tahan naungan. (Skripsi). - Fakultas Pertanian Universitas Brawijaya. Malang.

[22] Matsoukis, A., Gasparatos, D., Chronopoulou-Sereli, A. (2015): Mepiquat chloride and shading effects on specific leaf area and K, P, Ca, Fe andMn content of Lantana camara L. - Emirates Journal of Food Agriculture 27(1): 122-126. DOI: 10.9755/ ejfa.v27i1.17450 http://www.ejfa.info/.

[23] Mauro, R. P., Sortino, O., Dipasquale, M. (2014): Phenological and growth response of legume cover crops to shading. - Journal of Agricultural Science 152: 917931.

[24] Mondal, M. M. A., Puteh, A. B., Malek, M. A., Ismail, M. R., Rafii, R. E., Latif, M. A. (2012): Seed yield of mungbean (Vigna radiata (L.) Wilczek) in relation to growth and developmental aspects. - The Scientific World Journal 2012: 1-7. DOI: $10.1100 / 2012 / 425168$

[25] Mulyani, A., Sukarman, Hidayat, A. (2009): Prospek Perluasan Areal Tanam Kedelai di Indonesia [Prospect of soybean extensification in Indonesia]. - Jurnal Sumberdaya Lahan 3(1): 27-38.

[26] Niinemets, Ü. (2010): A review of light interception in plant stands from leaf to canopy in different plant functional types and in species with varying shading tolerance. Ecological Research 25: 693-714. DOI: 10.1007/s11284-010-0712-4.

[27] Öztürk, A., Demİrsoy, L., Demİrsoy, H. (2014): The effect of shading on net assimilation rate and relative growth rate in strawberry. - Anadolu Tarım Bilimleri Dergisi 29(3): 167173. https://www.cabdirect.org/cabdirect/abstract/20143414902

[28] Peksen, E. (2007): Non-destructive leaf area estimation model for faba bean (Vicia faba L.). - Science Horticultura 113: 322-328.

[29] Peng, X., Thevathasan, N. V., Gordon, A. M., Mohammed, I., Gao, P. (2015): Photosynthetic response of soybean to microclimate in 26-year-old tree-based intercropping systems in Southern Ontario, Canada. - PLoS ONE 10(6): 1-10. http://www.ncbi.nlm.nih.gov/pmc/articles/PMC4459881/pdf/pone.0129467.pdf.

[30] Polthanee, A., Promsaena, K., Laoken, A. (2011): Influence of low light intensity on growth and yield of four soybean cultivars during wet and dry seasons of Northeast Thailand. - Agricultural Sciences 2(2): 61-67. 
[31] Purcell, L. C., Salmeron, M., Ashloc, L. (2014): Soybean Growth and Development. - In: Arkansas Soybean Production Handbook. Division of Agriculture Research \& Extension. University of Arkansas System, Little Rock. https://www.uaex.edu/publications/ pdf/mp197/chapter2.pdf.

[32] Srikrishnah, S., Peiris, S. E., Sutharsan, S. (2012): Effect of shading levels on leaf area and biomass production of three varieties of Dracaena sanderiana L. in the dry zone of Sri Lanka. - Tropical Agricultural Research 23(2): 142-151. https://www.pgia.ac.lk/ files/Annual_congress/journel/v24_2/Journal/16.Srikrishna.pdf.

[33] Statistics Indonesia (2019): Agricultural Statistics. Center for Agricultural Data and Information System. - Ministry of Agriculture Republic of Indonesia, Jakarta, pp.118119.

[34] Su, B. Y., Song, Y. X., Song, C., Cui, L., Yong, T. W., Yang, W. Y. (2014): Growth and photosynthetic responses of soybean seedlings to maize shading in relay intercropping system in Southwest China. - Photosynthetica 52(3): 332-340. http://link.springer.com/ article/10.1007/s11099-014-0036-7.

[35] Sumarsono (2008): Analisis Kuantitatif Pertumbuhan Tanaman Kedelai. Jurusan Nutrisi dan Makanan Ternak. Fakultas Peternakan. - Universitas Diponegoro, Semarang.

[36] Sundari, T., Soemartono, Tohari, Mangoendidjojo, W. (2008): Anatomi daun kacang hijau genotipe toleran dan sensitif naungan leaf anatomy of tolerant and sensitive mungbean genotypes to shading. - Buletin Agronomi 36(3): 221-228.

[37] Valladares, F., Gianoli, E., Gómez, J. M. (2007): Ecological limits to plant phenotypic plasticity. - New Phytologist 176: 749-763. DOI: 10.1111/j.1469-8137.2007.02275.x.

[38] Valladares, F., Niinemets, U. (2008): Shading tolerance, a key plant feature of complex nature and consequences. - Annual Review of Ecology, Evolution, and Systematics 39: 237-257. DOI: 10.1146/annurev.ecolsys.39.110707.173506.

[39] Verdelli, D., Acciaresi, H. A.; Leguizamon, E. S. (2012): Corn and soybeans in a strip intercropping system: crop growth rates, radiation interception, and grain yield components. - International Journal of Agronomy. DOI: 10.1155/2012/980284.

[40] Wang, N., Huang, Q., Sun, J., Yan, S., Ding, C., Mei, X., Li, D., Zeng, X., Su, X., Shen, Y. (2014): Shading tolerance plays an important role in biomass production of different poplar genotypes in a high-density plantation. - Forest Ecology and Management 331: 40-49.

[41] Zhang, S., Ma, K., Chen, L. (2003): Response of photosynthetic plasticity of Paeonia suffruticosato changed light environments. - Environmental and Experimental Botany. 49: 121-133.

[42] Zhu, X. G., Long, S. P., Ort, D. R. (2010): Improving photosynthetic efficiency for greater yield. - Annual Review of Plant Biology 61: 235-261. DOI: 10.1146/annurevarplant-042809-112206. 